\title{
BOKO HARAM AND JIHAD IN NIGERIA
}

\section{Theo Brinkel and Soumia Ait-Hida \\ Netherlands Defence Academy, Department of International Security Studies}

\begin{abstract}
Nigeria has recently been confronted with increased terrorist activity by a group called Boko Haram. This group has been able to survive counterterrorist measures by the Nigerian government and has increased its attacks on targets inside and outside its traditional area of operation. On Christmas 2011, at least 25 churchgoers were killed. Earlier, Boko Haram hit the headquarters of the United Nations in Abuja, Nigeria's federal capital, in a suicide attack, leaving at least 23 people killed and more than 80 injured. This article will look into Boko Haram, its ideology, its methods, and its international connections. In order to determine whether or not the group is driven by religious motives, the authors consider Boko Haram's use of religion as an ideology, as an instrument for recruitment, as a legitimation of extreme violence and as a criterion for the selection of targets. These indicators will be examined in order to learn more about the character of Boko Haram, about its ideology, its methods, and its international connections. The authors conclude that Boko Haram is indeed primarily driven by religious motives while its members are motivated by a Jihadist version of Islam. They view themselves as believers of the only true interpretation of the Islamic faith. Their aim is to establish an Islamic state in Nigeria on the basis of the Sharia.
\end{abstract}

\section{Introduction}

On Christmas 2011, at least 25 churchgoers in Nigeria were killed in attacks by the radical jihadist group Boko Haram. Earlier, in November 2011, over 150 people had been murdered in what the Nigerian newspaper The Nation called "the

Scientia Militaria, South African Journal of Military Studies, Vol 40, Nr 2, 2012, pp. 1-21. doi: $10.5787 / 40-2-994$ most deadly attacks so far" of the same group. ${ }^{1}$ These attacks took place in the towns of Maiduguri, Damaturu and Potiskum and were aimed at churches, mosques, banks and police stations. There were condemnations from the 
head of the Organisation of the Islamic Conference, the Pope, the United Nations Security Council and the Secretary General of the United Nations. ${ }^{2}$ In 2012, violent attacks against churches and government institutions continued, causing over a hundred deaths in Kaduna, Bauchi and Plateau member states.

Until fairly recently, the focus of Boko Haram's activities had been in Northern Nigeria. However, in August 2011, Boko Haram hit the headquarters of the United Nations (UN) in Abuja, Nigeria's federal capital, in a suicide attack, leaving at least 23 people killed and more than 80 injured. With this onslaught, it seemed Boko Haram took its campaign to a new level. It was the first time terrorists in Nigeria attacked a presence of the international community in the form of an office of the UN. The attack was significant in another respect as well. It resembled an earlier attack against a UN office committed by al-Qaeda in the Islamic Maghreb (AQIM) in Algiers, the capital of Algeria.

Were AQIM and Boko Haram to combine their efforts, West Africa, a region already marked by instability, would face a further serious threat. Not only because of the violence of Boko Haram within Nigeria, but also because of the organisation's possible connections with the North African al-Qaeda offshoot, the AQIM. Early October 2011, during a meeting of Chiefs of Defence Staff (CDS) of the member states of the Economic Community of West African States (ECOWAS), the Nigerian CDS Chief Marshal Oluseyi Petinrin said that the upsurge in acts of terror in several countries including Nigeria required "urgent attention". 3

This article will look into the jihadist terrorist group called Boko Haram, its ideology, its methods, and its international connections. By what ideology is Boko Haram driven? How is Boko Haram positioned within the Muslim community in Nigeria? How does the group affect the relations between Muslims and Christians? Is Boko Haram part of an international jihadist terrorist network? These questions will be addressed in this article.

First, a short interpretative framework will be given in order to establish some clarity on the terms and definitions used in this text. Second, attention will be paid to the political, economic, ethnic and religious situation in Nigeria. Next, two paragraphs will deal with the objectives, the character and the actions of Boko Haram, as well as the position of Boko Haram in the international context. The article ends with the conclusion by the authors that, indeed, more international attention to jihadist violence in Nigeria is necessary. Much of the material used in 
this article is based on a paper that was published in Dutch by the Sen Foundation for International Cooperation and the Netherlands Defence Academy. ${ }^{4}$

\section{Interpretative framework}

As will be shown, Boko Haram can be typed as a jihadist terrorist organisation. Two terms used in this article need to be explained: terrorism and Jihadism. Terrorism is defined as the threat, the preparation or the actual act of serious violence directed against human beings, or acts aimed at creating damage disruptive to society in order to bring about social changes, terrify the population, or influence political decision-making. In doing so, terrorism aims at causing a psychological effect and needs publicity to achieve this. ${ }^{5}$ According to the UK strategy paper for countering terrorism, "Contest", there were about 11000 terrorist attacks in the world during 2009, causing nearly 15000 casualties, and in 2010 there were over 11500 attacks, causing over 13000 casualties. The vast majority of attacks were carried out by al-Qaeda and associated terrorist groups. Most attacks took place in Afghanistan, Pakistan, Somalia and Iraq, and the majority of the victims were Muslims. ${ }^{6}$

Jihad is a religious concept that works as an ideological framework. According to "Contest", the function of such an ideological framework is to offer its believers a coherent set of ideas that provide the basis for organised political action. ${ }^{7}$ Jihadist terrorism refers to a specific type of terrorism. Jihadism is derived from the Islamic concept of jihad. First and foremost, jihad is an inner struggle of the individual believer to obey God's commandments and avoid worldly temptations. However, there is an outward aspect of jihad as well. In this sense, the concept refers to defence of the Islamic religion, which is a duty of each believer. The concept of Jihadism is oriented towards this latter meaning. Jihadism can be defined as an extreme political ideology characterised by the divine endeavour to spread Islam over the whole world by waging a holy war against all unbelievers. Jihadist fighters oppose corrupt regimes in their own countries as well as in a more general sense, the economic, cultural, and political dominance of the West.

Jihadist terrorism today is generally related to al-Qaeda. According to Bruce Hoffman, al-Qaeda is not a hierarchical organisation, but must be seen as a network without a central leadership. ${ }^{8}$ Marc Sageman in fact calls it a "leaderless jihad," because in his view al-Qaeda does not have a central coordination, but consists of 
local networks, which each does its own operations. What coordination exists comes about in the continuing jihadist discourse on the internet. ${ }^{9}$

There is much debate about the extent to which religion does inspire violent groups. On the one hand, the International Crisis Group (ICG) has noted that religious differences and violence often serve as a cover for other issues, such as discrimination, the unequal distribution of resources, uneven economic power, poverty and marginalisation. This does not mean that, according to the ICG, religion is not important. Ethnicity and religion appear to have been connected to socioeconomic malaise and grievances about marginalisation. ${ }^{10}$

On the other hand, the importance of religion was shown in a BBC World Service "Who runs your world" survey of global attitudes toward power, conducted in 2005. According to the survey, three-quarters of the respondents in Africa said that religious leaders were the group they trusted most, compared to one third on a global basis. In Nigeria, the country under scrutiny in this article, $85 \%$ of respondents trusted religious leaders, and a comparable percentage would be prepared to give these leaders more power. On the question which factor would be most important in determining their identity, a majority of Africans answered religion. Only $6 \%$ named ethnicity as the strongest determining factor. ${ }^{11}$

This is not the place to give an in-depth exposé on religion and faith, but the following remarks may be relevant to this article. Religion is more than just an ideological framework or a legitimation for political use. Religion encompasses all dimensions of human life but relates to transcendent aspects as well. There is a whole body of belief that exists outside and independent of specific groups, which can be tapped for alternative resources for legitimation. In the case of jihadist terrorist organisations, religion is made part of the problem. When looking at a way out of this problem, religion should also be included in the considerations. Religious actors and religious arguments as well as religious communities should be made part of the solution.

The relationship between state fragility and terrorism is much debated. According to the relevant literature, poverty, and weak or failed states as such do not cause terrorism. Nor can terrorism be ended by economic development or tightening security only. Jessica Stern has enumerated circumstances and "grievances that give rise to holy war". ${ }^{12}$ According to her, these are among others a government's inability to provide basic services, a culture of violence, a growing number of 
unemployed young men, and humiliation. ${ }^{13}$ For terrorist groups, weak or failed states serve as a context within which they can move relatively freely and where they can deliver services that cannot be provided by the government, such as judicial structures, schooling, or social support. ${ }^{14}$ In addition, in corrupt, violent and failing states, such groups can show an alternative to the dominant political culture by leading an exemplary life that is marked by austerity, community service and rejection of corruption.

Violent groups may be inspired by religion. This can be very difficult to prove, as it is impossible for the academic observer to look into the soul of leaders and followers. What can be observed from outside is the use of religion as an ideology, as an instrument for recruitment, as a legitimation of extreme violence, and as a criterion for the selection of targets. These indicators will be dealt with below in order to learn more about the character of Boko Haram, about its ideology, its methods, and its international connections. In order to make this possible, the next paragraph will look into the political, socio-economic and religious context in Nigeria relevant to the emergence of Boko Haram. The section will therefore concentrate on Nigeria's state failure, its culture of violence, poverty and humiliation in relation to religious and ethnic identity. These were seen by Jessica Stern as the grievances that give rise to holy war.

\section{Grievances}

State failure was defined above as one of the grievances that may give rise to holy war. In 1914, the Colony and Protectorate of Nigeria came into existence out of two separate British protectorates in the North and the South of present-day Nigeria. After independence in 1960, Nigerian politics were dominated by three ethnic groups, each controlling a different region of the country: the Yoruba in the West, the Hausa-Fulani in the North and the Igbo in the East. Ethnic identities determined political allegiance. In 1966, a group called Young Majors took power and established military rule. A year later, a brutal civil war broke out, in which the eastern part of the country fought for independence. When the war ended in 1970, the unity of the state was restored. For long periods, Nigeria was governed by military rule. Military dictatorship became especially oppressive in the eighties under Generals Ibrahim Babangida and Sani Abacha.

With the death of Abacha, military dictatorship ended. In 1999, a democratic dispensation came into force. Olusegun Obasanjo became the first democratically 
elected president. According to the new constitution, which is still in force, Nigeria is a federation of 36 states and a federal capital territory of Abuja. In the meantime, Nigeria had become one of the poorest and most corrupt countries in the world and state institutions had lost all credibility. This can still be seen in the figures of the Corruption Perceptions Index 2010 of Transparency International. In it, Nigeria takes the $134^{\text {th }}$ position on a list of 180 registered countries. ${ }^{15}$ According to a report of the United States Congress, Nigerian security forces are accused of serious violations of human rights, such as torture and extrajudicial executions. ${ }^{16}$ Political elites in all parts of the country benefit from the income that is generated by oil. Revenues generally are not invested in the community, but are divided among the political elites.

Nigeria can be seen as an example of a failing state, i.e. a state that is not able to exert its legitimate power effectively in all of the country or in the relevant fields of state responsibility. In the 2011 Failed States Index, published by the Fund for Peace (FfP), Nigeria is $14^{\text {th }}$ on the list of most unstable states. According to the FfP, Nigeria's worst scoring indicators were Group Grievance, Uneven Development, Legitimacy of the State, Public Services, Security Apparatus, and Factionalised Elites. The titles of the indicators speak for themselves. More specifically, religious and communal divisions have resulted in violence in the Niger delta region, the central region, and the north. The FfP further reports that there is "endemic corruption," "deep distrust of the state, inadequate public services, and security forces that often operate with impunity." 17

It is important to take note of the fact that Nigeria is an African country, and, like other countries in Africa, it is not just the state that is relevant to society and the people living in it. In a recent study, Stephen Ellis showed that in Africa, there is a strong influence on the social life of non-state structures, communities and informal politics. Ellis writes,

The pretence that the official organs of government actually function in reality as they do on paper has become institutionalised in Africa over decades and it can easily be integrated into wider circuits of deception used by international operators who wish to hide their activities behind a screen of formality and law. ${ }^{18}$

In practice, Nigerian elites use the state as well as other sources of power and wealth for the benefit of themselves and their clientele. The weakness of the state provides space to political elites for enrichment and allows for corruption as an 
alternative way of financing services that in many other societies are considered of a public nature. In this practice, there is hardly any distinction between public and private funds. In an oil-rich country, such as Nigeria, elites can finance themselves with oil revenues, without having to consider the need for support of the general population in order to raise taxes. ${ }^{19}$ The same is true for security. For its part, security can be provided not only through formal institutions such as the police and the armed forces, but also through informal arrangements. Armed groups, organised around local or regional strongmen, can maintain order and security, but they may just as well turn into armed insurgents, criminal gangs, or protection rackets, and back into vigilante groups again. According to Ellis, there is no clear line between politically motivated violence on the one hand, and criminality and terrorism on the other. $^{20}$

In April 2011, elections took place for parliament, governors and president. The elections were won by Goodluck Jonathan, a candidate from the Christian south. According to the Fund for Peace (FfP), the elections were considered the nation's freest and fairest. There was, however, much violence. In the run-up to the elections, local-level candidates were abducted, killed or otherwise intimidated. After the polls, violence led to the death of hundreds and the displacement of thousands. $^{21}$

Apart from state failure, a culture of violence and poverty leads to other grievances that give rise to holy war. With 155 million inhabitants, Nigeria is the most populous country in Africa. The population is relatively young: the average age is 19,1 years. Over half the population lives below the poverty line, despite the fact that Nigeria is the largest oil producer of Africa. ${ }^{22}$ Over $40 \%$ of Nigerian oil is exported to the United States, which makes Nigeria the fourth largest oil supplier to that country. ${ }^{23}$ In addition, $5,74 \%$ of the oil imports into the European Union stem from Nigeria, which makes Nigeria the $6^{\text {th }}$ largest oil importer in the EU. ${ }^{24}$ Oil revenues make up $95 \%$ of export earnings, and $80 \%$ of budgetary revenues. The value of the GDP in 2011 was $\$ 418,7$ billion, the GDP per capita was $\$ 2600$. Growth in 2011 was 7,2\%. Nigeria's public debt was $17,9 \%$ of the GDP in $2011 .^{25}$

The country's wealth is, however, not used to combat poverty and inequality effectively. There exist substantial economic differences between the northern and the southern parts of the country. In the north, $72 \%$ of the population live below the poverty line; in the south, the figure is $27 \%$. An estimated $70 \%$ of the overall population has to make do with less than $\$ 1,25$ a day. ${ }^{26}$ Furthermore, Nigeria's oil is 
mainly found in the southern coastal area of the Gulf of Guinea. This region is affected by instability, political conflict and crime. A group called the Movement for the Emancipation of the Niger Delta (MEND) demands a greater share of oil revenues for the local population, if it does not actually take the oil itself. MEND is known for attacking oil installations, kidnapping personnel, and tapping oil from pipelines. Stolen oil is purchased with cash, weapons and cocaine. High-placed politicians, military personnel, and bureaucrats are said to be involved in this business, which is said to be worth over a billion US dollars a year. ${ }^{27}$ These practices not only cause loss of production and pollution, but further undermine the moral integrity of the public order and its leaders as well.

Nigeria suffers from failing state structures, a culture of violence and widespread poverty. There appear to be ample reasons for religious and ethnic groups to feel humiliated. There are nearly 350 ethnic groups, speaking about 250 different languages. The largest communities are the Hausa-Fulani, Igbo and Yoruba. About $50 \%$ of the population are Muslim, $40 \%$ are Christian, and $10 \%$ adhere to traditional African religions. Most Muslims live in the North, whereas Christians and believers of traditional African religions reside in the southern half of the country. The Hausa-Fulani are mostly Muslim, the Yoruba are half-Christian and half-Muslim, and the Igbo (who live in the south east) are mainly Christian. The southern half of the country has mostly been influenced by western politics, economy, culture and education.

According to Toni Johnson, in Nigeria, religion is one of the most important features of identity. ${ }^{28}$ Mainstream Muslims respect religious diversity and live side by side with the other people of the Book, the Christians. When local leaders sought to win support of the population, they used religion to rally people around them or to distance themselves from others. Radical Islam, expressing a version of Islam that takes the Quran literally, took root in Nigeria, as it did in other countries. These Muslims often hark back to the nineteenth-century Islamic rule of sheikh Usman dan Fodio and his heirs as a kind of golden century.

After the Islamic Revolution in Iran, violence broke out between Christians living in Northern Nigeria. Ethnic violence started between Yoruba and Hausa or between ethnic groups and the state in the oil-producing territories in the south. The debate on the introduction of Shaira law came up in the northern member-states. In 1980, an Islamic sect called the Maitatsine ("the one who curses") mobilised young poor, and rebelled against state representatives in the north. Over 4200 people died. 
The movement wanted to purify Nigerian Islam from western influences. The violence was stopped by the military regime in 1985. In 1986, Nigeria became a full member of the Organisation of the Islamic Conference. In reaction, Christians rebelled.

In October 1999, Governor Ahmed Sani, inspired by Saudi Arabia, announced the establishment as per 1 January 2000 of Sharia law as the sole legal system in Zamfara State. His aim was to purify society from decadence. ${ }^{29}$ Other member states followed suit. Today, Sharia law is in force in nine member states and three federal states have provinces where Sharia law is in force. This seems to contradict the constitution of Nigeria, which in article 10 states, "The Government of the Federation or of a State shall not adopt any religion as State Religion."30 Fearing their legal position in the member states in question would deteriorate, Christians living there protested. Violent religious conflicts broke out. In the north, whole Christian communities were expelled. In the south, militant Igbo's took revenge on Muslim Hausa immigrants from the north. ${ }^{31}$ Since 1999, about 12000 Nigerians have died in ethnic and religious violence. ${ }^{32}$

Violence did not stop there. During the presidential elections of April 2011, there was controversy over the candidate of the People's Democratic Party, the incumbent president, Goodluck Jonathan. He is a southerner who in January 2010 took over after the death in May 2009 of Umaru Yar'Adau, who hailed from the Islamic north of Nigeria. Traditionally, power had rotated between politicians from the north and south. Jonathan, however, remained as candidate, and won the presidential elections. ${ }^{33}$ In the eyes of many Muslims, the new president ought to have been a Muslim. After the elections, violence broke out in a number of northern states, killing over 1000 people. Businesses, churches and houses were destroyed and looted. According to the Nigerian Red Cross, about 74000 people were displaced. Most attacks were committed by uneducated, poor and possibly intoxicated young thugs, who may have been supported by radical Islamists. ${ }^{34}$

An important source for followers of radical groups is the Quranic schools for poor boys, the Almajiri. Such boys are sent out in the morning by their teachers to beg for food and money, and then get radical Islamic religious education later. The schools provide cheap education and imbue young boys with a radical interpretation of Islam, and promote a world-view that divides the world between true believers and infidels. According to the Vanguard, "the Almajiris came to be 
instruments of sectarian violence, biddable pawns in the hands of mischief makers."35

Boko Haram is not the only radical Islamic group in Nigeria that is prepared to use violence. There are many others, such as the predominantly Shiite Islamic Movement in Nigeria, led by Ibraheem Zakzaky, or the Izala Group, which gets support from Saoudi Arabia.

Several factors seem to come together in Nigeria in creating a climate, which is favourable to the emergence of extremist violent groups waging holy war. Violence is but one of the problems in Nigeria. The country suffers from corruption, a dysfunctional bureaucracy, ethnic and religious tensions, and an insurgency in the oil-rich Niger delta. This is the context within which the emergence of Boko Haram must be considered.

\section{Rise of Boko Haram}

Against the background of state failure, poverty and feelings of humiliation, the radical jihadist group Boko Haram emerged with the aim of overthrowing the government of Nigeria and establishing an Islamic state in the whole of the country. Boko Haram is rooted in the Islamic Yusufiyya sect, which is named after its founder Mohamed Yusuf. The sect started in Maiduguri, the capital of the federal state of Borno in the north-eastern part of Nigeria. In 2004, the group moved to Kanamma in the federal state of Yobe, close to the border with Niger. Since that time, Boko Haram has had a base there from which it organises its assaults.

Mohamed Yusuf was a charismatic preacher of violent extreme Islam. He was responsible for radicalisation of Boko Haram. In July 2009, he led a large-scale uprising in the member states of Bauchi, Borno, Kano, Katsina and Yobe. As a result of this revolt, 3500 people had been displaced, 1264 children orphaned and over 392 women widowed. In addition, 28 police officers, 5 prison warders and an undisclosed number of soldiers were killed. Furthermore, 48 buildings had been destroyed, including three primary schools, 12 churches and a magistrate's court. In all, there were between 800 and 1000 casualties and thousands of wounded, mainly supporters of Boko Haram. Muhammad Yusuf himself was captured and brutally killed in police custody. ${ }^{36}$ In September 2010, over 300 Boko Haram members attacked Bauchi prison and helped over 700 inmates to escape, including sect members who had been detained since the July 2009 revolt. ${ }^{37}$ 
After the death of Yusuf, abu-Mohammad abu-Bakr ibn Mohammad alShakwi - also known as Abubakar Shekau - became the new leader. During the riots of July 2009, he was shot in his leg. Shortly afterwards, the media suggested he was dead. The Nigerian police claimed to have killed him in 2010. He was indeed generally considered dead until, on 2 October 2010, his first statement came out as the leader of Boko Haram. The attacks and acts of violence of Boko Haram continued, and Shekau is allegedly in hiding in the desert between Chad and Sudan.

Boko Haram has used several names. One of them is Ahl al-Sunnah wa alJama'a 'ala Minhaj as-Salaf, which means "People of the Tradition of the Prophet and the Group according to the Salafist Method"; another is Jama'at Ahl al-Sunnah li Da'wah wal Jihad, which means "Community of the People of the Tradition for Preaching and Holy War". The first public declaration using the name Boko Haram appeared in August 2009. Boko Haram is said to have hundreds or even thousands of members. According to Freedom Onuoha, Boko Haram has over 280000 members across the 19 states of Northern Nigeria. ${ }^{38}$ The group draws its members from unemployed disaffected youth. It is organised in units that reflect the federal state structure of Nigeria and the provinces within the federal states. The leader of such a unit is called an emir.

As was remarked above, the religious character of Boko Haram can be observed by looking at its ideology, its way of recruitment, its legitimation of extreme violence and the selection of its targets.

The core of the ideology of Boko Haram is the introduction of strict Sharia law in the whole of Nigeria. That in itself is religious in character. The importance of religion can also be deduced from the name Boko Haram. Boko Haram means literally: "Western education is a sin". For Boko Haram, only education based on the lessons of the Qur'an and the Sunna as interpreted by the first generations of Muslims (Salaf) is acceptable as an alternative to Western and secular education. ${ }^{39}$ According to its leadership, the name Boko Haram has a broader meaning, implying the rejection of all kinds of western influence, such as crime, drugs, alcohol, homosexuality, lax morality, constitutional protection of the rights of women, and multiparty democracy. Strict Sharia law is meant to cleanse society of those influences. For Boko Haram, Nigeria is morally bankrupt and riven by political corruption and moral deprivation. The cooperation of the government of Nigeria with western countries, especially the United States, is denounced as well. 
The combat of poverty or economic empowerment hardly plays any role in the ideology of Boko Haram. In an opinion piece in the Nigerian newspaper The Nation, Festus Ereye gave a more cynical explanation of the ideology of Boko Haram., when he writes,

This is not your typical uprising driven by hunger. Even if we allow that extreme lack created the environment for the sect to rise, the group has not set out its agenda as that of economic empowerment. It does not promise the wretched of the earth a more prosperous tomorrow. The only swift exit from poverty it offers its clueless followers is to be blown to smithereens by IEDs. ${ }^{40}$

In the recruitment and cohesion of members of Boko Haram, religion plays a significant role. Members behave as if they belong to a religious sect. They usually pray in their own mosques and do not mingle with the local population. They can be recognised by their long beards and black headdresses. However, their first and foremost common characteristic is adherence to a specific form of radical Islam. The members see themselves as Muslims, who in their own opinion preach the only true interpretation of their religion. Boko Haram therefore is a predominantly religious and not an ethnically defined organisation.

God is invoked in the legitimation of extreme violence. In a recent YouTube video, the Boko Haram leader Shekau made the following remarks on the legitimation of extreme violence:

... there will certainly be a day when God will make things clear for the whole world to understand where we stand. To those that we kill, it has been established that they have constituted themselves as affront to the cause of God. This is a message we have for the world and especially those that have been making empty threats about us. ${ }^{41}$

The targets of Boko Haram's attacks symbolise what the group is fighting against: police stations, other government buildings and churches. Operations consist of assaults with firearms and explosives. Attacks usually take place on motorcycles. It must be noted that attacks have also been made on Muslim targets. Opponents of violence, political elites in the north and Islamic clerics who have adopted a western lifestyle and who participate in western political state structures have been assaulted. One example is the execution by Boko Haram of Bashir 
Kashara, a Wahhabi cleric in Maiduguri who spoke out against the violence in Northern Nigeria. ${ }^{42}$

Boko Haram is financed by several sources of income. The most important ones are contributions by members and donations by politicians, government functionaries and organisations within Nigeria. It is difficult to say how Boko Haram gets its weapons. The armed group MEND, which is active in the south of Nigeria, gets its arms by smuggling. Although both organisations differ ideologically, it is not unthinkable that Boko Haram benefits in a similar way from corruption, ineffective border control and smuggling. Stephany Schulze, citing a local source, says that some of Boko Haram's weapons probably enter the country via Chad. $^{43}$

Operations of Boko Haram are concentrated in the north of Nigeria, mainly in the federal states of Borno, Yobe and Bauchi. In the last two years, however, Boko Haram has extended its field of operations to include the federal state of Kano and the regions bordering the dividing line between the Islamic North and the Christian South of Nigeria. In 2009, Boko Haram started with an uprising in the town of Bauchi. The violence then spread to Yobe, Kano and Borno. After that, Boko Haram started to use suicide bombings and assassinations - first in the northern part of Nigeria, but the area of operations was extended to the south. Boko Haram bombed the police headquarters and the UN building in the federal capital of Abuja in June and August 2011, respectively. During Easter 2012, a Boko Haram suicide attack killed 40 people in Kaduna state.

There are few indications that the Nigerian authorities are able to suppress the capacities and the support for Boko Haram among the population of North Nigeria effectively. In April 2011, President Jonathan stated that he was going to apply a "carrot and stick" policy. On the one hand, he wanted to negotiate a ceasefire agreement; on the other, he wanted to combat terrorism. For the latter part of the policy, he sent more troops to the north, but there are few signs that this worked. On 12 June 2011, Boko Haram issued a list of conditions for negotiations with the government. Among these conditions were the unconditional release from prison of all Boko Haram members, the persecution of those responsible for the killing of Boko Haram leader Yusuf in 2009, and the strict application of Sharia law in 12 northern federal states of Nigeria. ${ }^{44}$ In 2012 , there seem to be no changes in the opposite stances of either the government or Boko Haram. 
Boko Haram operates on the basis of Jihadist ideological motives, as defined above. The grievances that Boko Haram expresses are explicitly articulated as religious politics. Boko Haram commits lethal attacks and other types of heavy violence with the aim of undermining the credibility and legitimacy of the constitutional order and of causing radical changes in politics and society. Its targets have religious significance and God is invoked as legitimation. A jihadist interpretation of Islam is the binding factor of Boko Haram's members.

\section{Boko Haram in an international context}

Recent developments show that Boko Haram has outgrown being a locally active group only, and that it has extended its range of operations to the federal level of Nigeria. There are even indications that Boko Haram must be considered in an international context. In March 2012, the Malian National Liberation Movement, known as Azawad, declared an independent republic in northern Mali. According to Nigeria's newspaper. The Punch, the group was led by at least 100 fighters of Boko Haram. ${ }^{45}$

The core leadership of al-Qaida is severely weakened and has suffered a serious blow by the death of Osama bin Laden on 2 May 2011. What constitutes the al-Qaida threat are groups using the al-Qaeda name, and acting with or without consultation with al-Qaida central leadership. The most important of these groups are al-Qaida in the Arabian Peninsula, AQIM, and Boko Haram. Regarding the last of these, the UK strategy for countering terrorism, Contest, says, "Further South, AQ-M [sic] has established contact with the Nigerian terrorist group, Boko Haram[,] and extended its reach into the volatile region of northern Nigeria. This area has long been of interest to the leadership of al-Qaida." ${ }^{46}$ The reason behind this interest may be that the existence of a whole region of fragile states creates an environment that allows for activities of radical and even terrorist groups.

It is not easy to prove the existence of formal links, but there are several indicators of a rapprochement between Boko Haram and the al-Qaida network. Below, some indicators of this development are given in a chronological order.

- In June 2009, Abu Yahya al-Libi of Al-Qaeda central gave a statement on Jihadist internet forums in which he encouraged Islamist militant groups in Northern Africa to unite under the leadership of AQIM, a terrorist organisation based in Algeria. ${ }^{47}$ 
- This statement was followed on 9 August of that year by a statement of Umaru, then acting leader of Boko Haram, who said, "Boko Haram is just a version of the al-Qaeda which we align with and respect. We support Osama bin Laden, we shall carry out his command in Nigeria until the country is totally Islamised. ${ }^{, 48}$ In this statement, Umaru claimed to speak on behalf of Boko Haram. He was probably referring to an earlier statement by Osama bin Laden who called Nigeria "ripe for Jihad". 49

- On 2 October 2010, a so-called Eid ul Fitr Declaration was published on Jihadist internet forums, under the heading of "al-Andalus", the banner of AQIM. In the declaration, Shekau, the current leader of Boko Haram, called upon Muslims in Nigeria to take on Jihad in order to defend Islam against its enemies. He further stated that Boko Haram is totally devoted to implementing the "programme of the Prophet" and to the installation of the Sharia. He rejected the legitimacy of the Nigerian state, which, according to Shekau, was founded by colonialism after murdering Muslims, destroying mosques, and de-sacralising the Qur'an. He added that any government not committed to the Sharia, including secular, Christian, and Shiite states, are to be considered enemies. Shekau praised al-Qaeda and its regional branches and leaders in Iraq, Yemen and North Africa, including al-Shabaab in Somalia and the holy warriors in Pakistan, Chechnya and Kashmir. He specifically mentioned Mullah Omar, bin Laden, and Abdul Wadud, the emir of AQIM. ${ }^{50}$

In the same period, posters appeared on the streets of Maiduguri presenting Boko Haram, the name of Shekau, and the logo of AQIM. The population was warned not to be helpful to the police or to come near soldiers guarding the city at night. Every Muslim who opposed the introduction of the Sharia was threatened with murder. ${ }^{51}$ A parallel development between Boko Haram and AQIM can be detected in the selection of targets, such as the attacks on the UN office in 2007 in Algiers and in 2011 in Abuja. The relation with AQIM is confirmed at the beginning of a recent YouTube video of Boko Haram. On it, there is the logo of two crossed Kalashnikov rifles around a Quran and a black Islamist flag, which mirrors the one that is used by AQIM. ${ }^{52}$ Like AQIM, Boko Haram has started using YouTube videos to proclaim its message. 
The possibility of links between Boko Haram and the al-Qaida network and al-Shabaab in Somalia is confirmed by US officials, such as general Carter Ham, the Commander of US Africa Command. Ham said,

What is most worrying at present is, at least in my view, a clearly stated intent by Boko Haram and by al-Qaeda in the Islamic Maghreb to coordinate and synchronise their efforts. I'm not so sure they're able to do that just yet, but it's clear to me that they have the desire and intent to do that.

He believes that a pan-African terrorist alliance would vastly increase security threats to Africa and the United States. ${ }^{53}$

\section{Conclusions}

In Nigeria, there is increased terrorist activity by the group called Boko Haram. Its members are motivated by a Jihadist version of Islam. They view themselves as believers of the only true interpretation of the Islamic faith. Their aim is to establish an Islamic state in Nigeria on the basis of the Sharia. The group has been able to survive counterterrorist measures by the Nigerian government and has increased its attacks on targets inside and outside its traditional area of operation. The authorities have not been able to suppress Boko Haram or diminish its support among the population of Northern Nigeria. In 2011 and the first half of 2012, a new wave of attacks by Boko Haram hit the country, this time in the capital and directed against international targets.

The violence by Boko Haram entails three kinds of confrontation. First, there is polarisation within the Muslim community between moderate Muslims and their leaders, who reject the use of violence, and Jihadist terrorists. Second, there is polarisation between Muslims and Christians. Relations between the two religious groups had already been tense. As a result of the actions of Boko Haram, a vicious cycle of attacks and revenge came about, turning the confrontation into a nationwide interreligious conflict. Boko Haram may be a small group, but in a fragile state such as Nigeria, there is a risk that polarised groups support large-scale violence as a means to settle affairs, or that the population will ask for a return to military dictatorship in order to restore security.

Finally, there is polarisation between the western-dominated international order and its symbolic presence in the form of the UN Headquarters in Abuja, and 
the Islamic purity as upheld by Boko Haram, which rejects all things western. This may be seen as an expression of the international jihad, and through it, one of alQaida's major offshoots, AQIM, may get a foothold in one of Africa's most important countries. The possibility of international connections between Boko Haram and AQIM has triggered international support from intelligence communities in the United States and Great Britain. The rapprochement between AQIM and Boko Haram must be taken seriously. AQIM has the technical know-how, the organisational skills, and the logistic capacity to make bombs and to commit suicide attacks. They also have good knowledge of the Sahel. Boko Haram, for its part, may not always be effective, but the group has an almost inexhaustible reservoir of members and potential mujahedeen (they who strive or struggle on behalf of Islam).

There are serious concerns that Boko Haram and AQIM may strengthen their ties and cooperation. Nigeria is a major player in the West African region, which is of growing importance for the international economy and the fight against organised crime, piracy and terrorism. Western companies invest heavily in the country. The economic ties of Nigeria with the West are important. These may be threatened if instability is further increased.

In the long term, it is relevant to note that Boko Haram is primarily driven by religious motives. Religion, therefore, has become part of the problem, so religion has to become part of the solution. In fact, Boko Haram seems to be driven by the desire to convert Nigerian society to a radical type of Islam. Religious communities, religious leaders, and faith-based nongovernmental organisations (NGOs) are well connected to African societies. They should be included in finding long-term solutions.

Still, it is important that Nigeria is not seen in terms of combating terrorism or combating al-Qaida only. That could draw attention away from context in which terrorist organisations can flourish, such as poverty, corruption and state failure. These are the circumstances that are conducive to a climate in which organisations such as Boko Haram come about and gain credibility and support. According to Nigerian analyst Chris Ngwodo, Boko Haram is "a symptom of decades of failed government and elite delinquency finally ripening into social chaos". ${ }^{54}$ It should not be forgotten that it is an aim in itself to help develop the north of the country economically, socially and otherwise. Development is and should be a good policy in and of itself for improving the life of Nigerian citizens not directly profiting from the oil revenues in the south. There is a whole complex of socio-economic 
development, ending corruption, and fostering security as objectives that have value in and of themselves. They are worthy of pursuit irrespective of the existence of radical groups. This is a major responsibility of the government of Nigeria, but is a task for the international community - both states and NGOs - as well.

\section{Endnotes}

1 "Boko Haram: Exodus in Yobe as death toll hits 150". The Nation. 7 November 2011. <http://www.thenationonlineng.net/2011/index.php/news/25500-bokoharam-exodus-in-yobe-as-death-toll-hits-150.html> Accessed on 15 November 2011.

${ }^{2}$ Ibid.

3 "Petinrin Lamends over Increasing Terrorist Acts in Ecowas Member States", National Accord Newspaper, 5 October 2011, $<$ http://nationalaccordnewspaper.com/index.php?option=com_content\&view $=$ article\&id=1971:petinrin-laments-over-increasing-terrorist-acts-in-ecowasmember-states\&catid=45:political-news\&Itemid=68> Accessed on 20 October 2011.

${ }^{4}$ Ait-Hida, S \& Brinkel, T. Jihadistische organisaties in Noord Afrika; Drijfveren, daden en deelgenoten van AQIM en Boko Haram. Den Haag: Sen Foundation voor Internationale Samenwerking en Nederlandse Defensieacademie, 2011.

${ }^{5}$ Nationaal Coordinator Terrorismebestrijding en Veiligheid, <http://www.nctb.nl/onderwerpen/terrorismebestrijding/wat_is_terrorisme/> Accessed on 19 April 2012.

${ }^{6}$ Contest: The United Kingdom's strategy for countering terrorism. HM Government. July 2011.

<http://www.homeoffice.gov.uk/publications/counter-terrorism/counterterrorism-strategy/strategy-contest?view=Binary $>$ Accessed on 20 October 2011.

${ }^{7}$ Contest op. cit., p. 35.

${ }^{8}$ Hoffman, B. Inside terrorism. New York: Columbia University Press, 2006, 39.

${ }^{9}$ Sageman, M. Leaderless Jihad: Terror networks in the twenty first century. Philadelphia: University of Philadelphia Press, 2008, 143.

${ }^{10}$ Lessons from Nigeria's 2011 elections. Policy Briefing. International Crisis Group. 15 September 2011. $<$ http://www.crisisgroup.org/ /media/Files/africa/west- 
africa/nigeria/B81\%20-

$\%$ 20Lessons\%20from\%20Nigeras\%202011\%20Elections.pdf> Accessed on 20 October 2011.

11 "Africans trust religious leaders". BBC News. 14 September 2005.

<http://news.bbc.co.uk/2/hi/africa/4246754.stm> Accessed on 14 November 2011.

${ }^{12}$ Stern, J. Terror in the name of God: Why religious militants kill. New York: Harper Collins, 2003, 285.

13 Ibid.

${ }^{14}$ Contest op. cit., p. 33.

15 Transparency International, Corruption Perception Index 2010, <http://www.transparency.org/policy_research/surveys_indices/cpi/2010/res ults> Accessed on 5 July 2011.

${ }^{16}$ Lauren Ploch, Nigeria: Elections and issues for Congress. Congressional Research Service, 1 April 2011.

<http://www.fas.org/sgp/crs/row/RL33964.pdf> Accessed on 6 July 2011.

${ }^{17}$ Failed States Index 2011. <http://www.fundforpeace.org/global/library/cr-11-14fs-failedstatesindex2011-1106p.pdf $>$ Accessed on 19 October 2011.

${ }^{18}$ Ellis, S. Season of rain: Africa in the world. London: Hurst, 2011, 37.

${ }^{19}$ Ellis op. cit., p. 106.

${ }^{20}$ Ellis op. cit., p. 103.

${ }^{21}$ Nigeria: Unfinished business after the election. UNLock Update Report 13,

December 2010 - May 2011. Washington, DC: The Fund for Peace.

<http://www.fundforpeace.org/global/?q=cr-11-18-ul> Accessed on 20 October 2011.

${ }^{22}$ CIA World Factbook Nigeria. <https://www.cia.gov/library/publications/theworld-factbook/geos/ni.html> Accessed on 17 March 2011.

${ }^{23}$ Country Analysis Briefs: Nigeria. US Energy Information Administration. August 2011. <http://205.254.135.24/countries/cab.cfm?fips=NI>Accessed on 21 October 2011.

${ }^{24}$ Registration of crude oil imports and deliveries in the European Union (EU27), Period 1-3/2011. European Commission Directorate-General for Energy. $<$ http://ec.europa.eu/energy/observatory/oil/doc/import/coi/eu-coi-fromextra-eu-2011-01-03.pdf> Accessed on 21 October 2011.

${ }^{25}$ CIA World Fact Book Nigeria. Last Updated October 16, 2012, <https://www.cia.gov/library/publications/the-world-factbook/geos/ni.html> Accessed on 24 October 2012. 
${ }^{26}$ US Department of State. Background note Nigeria. 20 October 2011. <http://www.state.gov/r/pa/ei/bgn/2836.htm> Accessed on 19 December 2011.

${ }^{27}$ Ellis op. cit., p. 12.

${ }^{28}$ Johnson, T. Backgrounder Boko Haram. Council on Foreign Relations. 31 August 2011. <http://www.cfr.org/africa/boko-haram/p25739> Accessed on 20 October 2011.

${ }^{29}$ Meredith, M. The state of Africa: A history of fifty years of independence. London: Free Press, 2006, 586.

${ }^{30}$ Constitution of the Federal Republic of Nigeria. <http://www.nigerialaw.org/ConstitutionOfTheFederalRepublicOfNigeria.htm\#Powers_of_Fede ral_Republic_of_Nigeria> Accessed on 16 April 2012.

${ }^{31}$ Meredith op. cit., p. 586.

${ }^{32}$ Ploch, op. cit.

${ }^{33}$ See also Nigeria: Unfinished business ... op. cit.

${ }^{34}$ Lessons from Nigeria's 2011 elections op. cit.

35 "Almajiri Education: Modern Gang-Up against Ancient Tradition", Vanguard, April 26, 2012, <http://www.vanguardngr.com/2012/04/almajiri-educationmodern-gang-up-against-ancient-tradition/> Accessed on 8 August 2012.

${ }^{36}$ Onuoha, FC. "The audacity of the Boko Haram: Background, analysis and emerging trend". Security Journal. 13 June 2011. 6. <http://dx.doi:10.105/sj.2011.15> Accessed on 19 April 2012.

${ }^{37}$ Onuoha op. cit., p. 6.

${ }^{38}$ Onuoha op. cit., p. 4.

39 The “Boko Haram” tragedy: Frequently asked questions. Minna: Da'wah Coordination Council of Nigeria. 2009, 14 .

${ }^{40}$ Ereye, F. "Here comes the Ministry for Northern Affairs". The Nation. 15 April 2012.

<http://www.thenationonlineng.net/2011/index.php/columnist/sunday/43124 -here-comes-the-ministry-for-northern-affairs.html> Accessed on 19 April 2012.

${ }^{41}$ Obinna, O. "This is our mission, by Boko Haram”. The Nation. 13 April 2012. <http://www.thenationonlineng.net/2011/index.php/news/42964-this-is-ourmission-by-boko-haram.html> Accessed on 19 April 2012.

${ }^{42}$ Waldek, L \& Jayasekara, S. "Boko Haram: The evolution of Islamist extremism in Nigeria”. Journal of Policing, Intelligence and Counter Terrorism 6/2. October 2011. 168-178. 
<http://dx.doi.org/10.1080/18335330.2011.605217> Accessed on 16 April 2012.

${ }^{43}$ Schulze, S. Nigeria: The Boko Haram battle. International Relations and Security Network. 7 September 2009. <www.isn.ethz.ch/isn/current-affairs/securitywatch/detail/?id=105612\&Ing=en > Accessed on 18 March 2011.

${ }^{44}$ Zenn, J. "Boko Haram exploits sectarian divisions to incite civil war in Nigeria". Terrorism Monitor IX/18. 5 May 2011.

45 "Boko Haram spreads terrorist campaign to Mali". The Punch. 10 April 2012. <http://www.punchng.com/news/boko-haram-spreads-terror-campaign-tomali/> Accessed on 16 April 2012.

${ }^{46}$ Contest op. cit., p. 23.

47،"'Boko Haram Releases Eid-al-Fitr Address via al-Qaeda in North Africa's Media Division Calling on Muslims to Wage Jihad, Bukisa, <http://www.bukisa.com/articles/366667_boko-haram-releases-eid-al-fitraddress-via-al-qaeda-in-north-africas-media-division-calling-on-muslims-towage-jihad > Accessed on 17 March 2011.

48 "Nigeria: Boko Haram - We're Raedy for Battle, New Leader Says", Allafrica, 15 August 2009, <http://allafrica.com/stories/20090814 0646.html> Accessed on 4 October 2010.

${ }^{49}$ NRC Handelsblad. 28 July 2009.

${ }^{50}$ For instance <http://ansar1.info/index.php $>$ Accessed 18 March 2011.

51 "Quick Items: Boko Haram and Al Shabab", Sahel Blog; Covering Politics and Religion in the Sahel and the Horn of Africa, <http://sahelblog.wordpress.com/2010/10/22 /quick-items-boko-haram-andal-shabab/> Accessed on 20 February 2011.

52 Ogunwale, G., Boko Haram Boasts in Video, The Nation. 13 April 2012. <http://www.thenationonlineng.net/2011/index.php/news/42995-bokoharam-boasts-in-video.html> Accessed on 19 April 2012.

53 Leigh, K. "Nigeria's Boko Haram: Al-Qaeda's new friend in Africa?" Time. 31 Augustus 2011. <http://www.time.com/time/printout/0,8816, 2091137,00.html> Accessed on 20 October 2011.

${ }^{54}$ Johnson op. cit. 